\title{
Experiences and narratives of patients with type 2 diabetes mellitus in the city of Salvador (Bahia) related to the difficulties in changing lifestyle behaviors
}

\author{
I ${ }^{1}$ Tiago Pereira de Almeida, ${ }^{2}$ Paulo Gilvane Lopes Pena I
}

Abstract: It is considerably difficult for type 2 diabetes patients to change lifestyle according to professional guidelines. This contributes to controlling the disease below what is desirable and could increase morbimortality and health system costs with complications that could have been avoided. It is important to know this phenomenon for better intervention, therefore, this qualitative study explores experiences and narratives of 10 diabetic patients in the city of Salvador (state of Bahia, Brazil), comparing them to the literature to analyze how health determinants may influence them. It is concluded that it is a multifactorial phenomenon and aspects such as conceptions about the disease and its control, use and access to health care, professional-patient relationship, social support and environment personalize each experience with the disease, which facilitates or not the motivation for change. Health professionals and public authorities should be sensitized to such aspects, and will find suggestions in this article that contribute to mitigating difficulties and facilitating a preventive lifestyle for patients.

Keywords: Type II diabetes mellitus; Lifestyle; Qualitative study; Prevention and control; Social determinants of health.
${ }^{1}$ Federal University of Bahia. Salvador-BA, Brazil (ssa.tiago@ outlook.com).

ORCID: 0000-0001-8002-7227

${ }^{2}$ Federal University of Bahia. Salvador-BA, Brasil (pena@ufba.br). ORCID: 0000-0001-9653-5509

Received on: 03/01/2019

Approved on: 18/11/2019 Reviewed on: 14/10/2021 


\section{Introduction}

Brazil has the fourth largest world population of patients with type 2 diabetes mellitus (DM2), with 12.5 million diagnosed cases (IDF, 2017). In the city of Salvador, 6.3\% of the population was diagnosed with diabetes (BRASIL, 2019).

DM2 involves genetics and lifestyle. As it usually starts at the age of 40, the current scenario of an inversion in the age pyramid in the country has increased its incidence, also associated with the growth of sedentary lifestyles and an unbalanced diet, which are its main risk factors (BRASIL, 2019; SBD, 2017).

DM2 is characterized by persistent insulin resistance and hyperglycemia and can lead to complications in the long term, such as poor visual acuity or blindness, peripheral neuropathy, limb amputation and renal insufficiency. It also increases the risk of myocardial infarction and stroke, the leading causes of death in the Western world (SBD, 2017). Even when such complications are not fatal, they still bring morbidity and make the health system more expensive with hospitalizations and highly complex technological procedures (CLARK, 2013; SBD, 2017).

These are complications that can be avoided with therapeutic adherence and changes in lifestyle behaviors. Lifestyle changes are the permanent changes in the individual's habits, incorporating, in the context of DM2, a diet rich in fiber, low in calories, minimal simple carbohydrates and regular physical activity (IDF, 2017; SBD, 2017). Despite their importance, patients have difficulty implementing them effectively (COSTA et al., 2011; PÉRES et al., 2007; PUN; COATES; BENZIE, 2009).

Though apparently restricted to individual choices, lifestyle, according to the World Health Organization (2004), is the "set of habits and customs that can be influenced, modified, encouraged or inhibited by the prolonged process of socialization" (p. 37). Therefore, it is possible to understand lifestyle changes from a social perspective (COSTA et al., 2011), which goes beyond the individualistic approach.

This concept is connected to the social determinants of health (BUSS; FILHO, 2007), which are "social, economic, cultural" (p. 78) and environmental factors, among others, that influence health-related phenomena. In fact, analyzing their influence on lifestyle changes becomes imperative for an in-depth understanding of the difficulty in changing behaviors. 
This understanding is the problem that motivates this study, which has the general objective of analyzing the experiences of DM2 patients regarding their difficulties with changing lifestyle behaviors. As a specific objective, the study seeks to understand the relationship between such difficulties and social determinants.

\section{Methodology}

The theoretical foundation of this study is based on the hermeneutic-dialectic method. It recognizes scientific validity and produces knowledge in the subject's intersubjectivity, exposed through language, when analyzed and compared to the current literature (MINAYO, 2014). To this end, a semi-structured interview was carried out with our own material, participant observation and a field diary, which are common resources of qualitative studies (MINAYO, 2014).

Knowing the life narratives of the subjects facing the researched topic is effective in understanding their subjectivity (LIRA; CATRIB; NATIONS, 2003), as it leads them to recall, in an organized way, aspects that are personally relevant to their experiences. Thus, the interviews encouraged the participants to produce their narratives of life with the disease.

Visits were made to two Family Health Units and a State Diabetes Reference Center (represented here with the acronym RC). Participants were chosen through conversations with professionals from these units and by reading medical records that met the inclusion criteria: having a diagnosis of DM2, living in Salvador and being known by professionals who assist them in creating eating and/or physical activity habits.

Ten interviews were carried out, with five patients from the Family Health Units and five from the RC. Looking for participants assisted in these two different services is relevant to understanding whether their characteristics influence the difficulty with lifestyle changes. We also looked for participants with versatile characteristics; therefore, people with different profiles may report similar things and particularities of subgroups may be noted. Thematic saturation was obtained with the ten interviews.

The first contact with potential participants took place in their assistance units. Upon signing the informed consent, their interviews took place on an agreed day, at their homes or in another chosen location. 
Interviewees from the Family Health Units live or work nearby the units. Those from RC represented different regions of the city. Family members and other interested people also took part in the interviews, which expanded the possibilities of appropriate narratives aligned with the objectives. The informed consent form was signed by all who participated.

The content analysis technique (MINAYO, 2014) was used to categorize the interview reports into common themes. These were then compared with the literature and grouped into larger thematic axes of discussion.

This study was approved by the Ethics Committee for Research with Human Beings of the Faculty of Medicine of Bahia, under protocol number 2.232.066.

\section{Results and Discussion}

The tables below present pseudonyms and the characteristics of the interviewees:

Table 1. Characteristics of the interviewees from the Family Health Units

\begin{tabular}{|l|l|l|l|l|l|}
\hline & Claudionor & Milton & Conceiçáo & Mauro & Ivete \\
\hline $\begin{array}{l}\text { Administrative } \\
\text { region }\end{array}$ & $\begin{array}{l}\text { Historic } \\
\text { Center }\end{array}$ & $\begin{array}{l}\text { Historic } \\
\text { Center }\end{array}$ & City center & City center & $\begin{array}{l}\text { Boca do Rio/ } \\
\text { Patamares }\end{array}$ \\
\hline Age & 72 & 63 & 68 & 42 & 50 \\
\hline Disease length & 16 years & 23 years & $\begin{array}{l}\text { Can't } \\
\text { remember }\end{array}$ & 6 years & 24 years \\
\hline Place of birth & $\begin{array}{l}\text { Bahia state } \\
\text { countryside }\end{array}$ & Minas Gerais & $\begin{array}{l}\text { Bahia state } \\
\text { countryside }\end{array}$ & Salvador & $\begin{array}{l}\text { Bahia state } \\
\text { countryside }\end{array}$ \\
\hline Occupation & Retired farmer & $\begin{array}{l}\text { Retired truck } \\
\text { driver }\end{array}$ & $\begin{array}{l}\text { Retired } \\
\text { cleaning lady }\end{array}$ & $\begin{array}{l}\text { Retired } \\
\text { doorman }\end{array}$ & $\begin{array}{l}\text { Worked at } \\
\text { a restaurant } \\
\text { before and now } \\
\text { owns a small } \\
\text { market }\end{array}$ \\
\hline Caregiver & $\begin{array}{l}\text { Her daughter } \\
\text { (Benedita) }\end{array}$ & No & No & $\begin{array}{l}\text { His wife } \\
\text { (Madalena) }\end{array}$ & No \\
\hline Religion & Evangelical & Catholic & Didn't say & Didn't say & Didn't say \\
\hline Comorbidity & HAS & No & Smoking & No & $\begin{array}{l}\text { Previous } \\
\text { bariatric } \\
\text { surgery }\end{array}$ \\
\hline
\end{tabular}

to be continued... 


\begin{tabular}{|l|l|l|l|l|l|}
\hline & Claudionor & Milton & Conceição & Mauro & Ivete \\
\hline $\begin{array}{l}\text { Disease } \\
\text { Complications }\end{array}$ & $\begin{array}{l}\text { Lower } \\
\text { extremity } \\
\text { amputation, } \\
\text { renal } \\
\text { insufficiency, } \\
\text { AV block }\end{array}$ & No & No & $\begin{array}{l}\text { Lower } \\
\text { Extremity } \\
\text { Amputation }\end{array}$ & No \\
\hline $\begin{array}{l}\text { Took part of the } \\
\text { interview }\end{array}$ & Benedita & --- & $\begin{array}{l}\text { Community } \\
\text { agent }\end{array}$ & Madalena & --- \\
\hline
\end{tabular}

Source: the author

Table 2. Characteristics of the interviewees from the RC

\begin{tabular}{|c|c|c|c|c|c|}
\hline & Reginaldo & Zé & Jurandir & Doroteia & Bernadete \\
\hline $\begin{array}{l}\text { Administrative } \\
\text { region }\end{array}$ & $\begin{array}{l}\text { Tancredo } \\
\text { Neves }\end{array}$ & $\begin{array}{l}\text { Salvador } \\
\text { suburb }\end{array}$ & Liberdade & $\begin{array}{l}\text { Salvador } \\
\text { suburb }\end{array}$ & Liberdade \\
\hline Age & 66 & 49 & 66 & 69 & 75 \\
\hline Disease length & 40 years & 21 years & 7 years & 18 years & 2 years \\
\hline Place of birth & Salvador & Salvador & Salvador & $\begin{array}{l}\text { Bahia state } \\
\text { countryside }\end{array}$ & $\begin{array}{l}\text { Bahia state } \\
\text { countryside }\end{array}$ \\
\hline Occupation & $\begin{array}{l}\text { Retired } \\
\text { bricklayer }\end{array}$ & $\begin{array}{l}\text { Company } \\
\text { worker, now } \\
\text { away from work }\end{array}$ & $\begin{array}{l}\text { Retired } \\
\text { bricklayer }\end{array}$ & $\begin{array}{l}\text { Ice cream } \\
\text { store owner }\end{array}$ & $\begin{array}{l}\text { Retired shop } \\
\text { assistant }\end{array}$ \\
\hline Caregiver & His wife & $\begin{array}{l}\text { His wife } \\
\text { Divorced a few } \\
\text { months ago }\end{array}$ & His wife & $\begin{array}{l}\text { Private } \\
\text { caretakers }\end{array}$ & No \\
\hline Religion & Didn't say & Catholic & Evangelical & Evangelical & Evangelical \\
\hline Comorbidity & $\begin{array}{l}\text { SAH, previous } \\
\text { stroke }\end{array}$ & No & $\begin{array}{l}\text { SAH, previous } \\
\text { heart attack, } \\
\text { obesity }\end{array}$ & SAH & SAH \\
\hline $\begin{array}{l}\text { Disease } \\
\text { Complications }\end{array}$ & AV block & $\begin{array}{l}\text { Lower } \\
\text { extremity } \\
\text { amputation }\end{array}$ & No & Blindness & $\begin{array}{l}\text { Frequent } \\
\text { hypoglycemia }\end{array}$ \\
\hline $\begin{array}{l}\text { Took part of } \\
\text { the interview }\end{array}$ & --- & --- & --- & Her caretaker & $\begin{array}{l}\text { Her goddaughter } \\
\text { (Antonieta), } \\
\text { granddaughter } \\
\text { and husband } \\
\text { (Vargas) }\end{array}$ \\
\hline
\end{tabular}

Source: the author 
In the tables, the administrative regions of the municipality (SEDUR, 2008) represent the neighborhoods where the participants live. Although the "Historical Center" is considered part of the city center, here we decided to differentiate the touristic area from the commercial center, which also illustrates the different areas of the Family Units where some interviewees came from.

According to common themes addressed in the interviews and their comparison with the literature, the difficulty with changing lifestyle was classified into five thematic axes of discussion, which are effectively connected to known and validated social determinants of health (BUSS; FILHO, 2007):

1 - Conceptions about the disease and its control. Buss and Filho (2007) point out that "it is very difficult to change risk behaviors without changing the cultural norms that influence them" (p. 86). The subject's cultural conceptions influence their relationship with their illness, consequently shaping their behavior (SATO et al., 2016). In this axis, we discuss the interviewees' common beliefs and conceptions about DM2, which are culturally constructed, and guidelines for changes in their diet.

2 - Use and access to health care. The easy access to health care is also a social determinant (BUSS; FILHO, 2007). Here we discuss how care services are used, when there is access to them.

3 - Professional-patient relationship. The quality of the relationship between the patients and their healthcare provider can be analyzed from a social perspective (BUSS; FILHO, 2007). Possible causes for behaviors that facilitate or hinder lifestyle changes are analyzed in this axis.

4 - Social support. The sick person's relationships, the lack of relationships or how they are built may be supportive or not (BUSS; FILHO, 2007), and are the object of analysis in this axis.

5 - Environment. In this axis, we analyze external factors, the environmental and economic macrodeterminants corresponding to the space where the subjects are and their living conditions imposed by their social situation (BUSS; FILHO, 2007).

\section{Conceptions about the disease and its control}

Due to its generally asymptomatic character, DM2 may not be recognized as a disease, leading patients to ignore the need for changes in lifestyle (BARSAGLINI, 2006; COSTA et al., 2011; SILVA, 2000). 
To me it's as if I didn't have it. I don't take medication for a long time and I don't feel anything (Conceição).

(The doctor) told me to take this medication, I started taking it and my life went on without any problem. I don't feel anything, I'm okay, so let's just ignore what the doctor said (Zé).

Most interviewees value the prescribed medication, presenting less difficulty with adherence. A techno-scientific society legitimizes the belief in medicine as a practical solution to human problems (DANTAS, 2009). Therefore, prescriptions represent the medical-scientific authority and what is expected from an appointment with a doctor. Furthermore, developing the habit of using it seems less tiresome when compared to eating habits and physical activity (COSTA et al., 2011; PÉRES et al., 2007).

The doctor told me to take these pills, I think it's better, more efficient [...]. My solution is to do physical activity and eat less, really toe the line. I should toe the line a little more though. (Milton)

I was taking the best medication [...]. To be honest, I know all about it, I read a lot about it, but I've never really followed what is recommended (Ivete).

Hypoglycemia is a possible consequence in the treatment of DM2. For those who had a crisis, it is a feared sensation, reinforcing the idea that it is better to maintain hyperglycemia (MOL; LAW, 2012). It is discouraging to think that lifestyle changes may contribute to hypoglycemia.
All my life with a sugar level of 500 without knowing it, eating everything I wanted, doing everything I was supposed to do. When you find out you have diabetes, you start to control it, your sugar levels go down and you start feeling sick. You even think it's bad, because when your sugar level was high, you were feeling fine (Mauro).
I'm just afraid my sugar level gets low. If it's high, it makes no difference, I don't feel anything. I won't stop eating all I want (Reginaldo).

The belief in the cure of DM2, mainly through religiosity, was also mentioned by the interviewees. This makes it difficult to accept the chronicity of their condition and the need for behavioral surveillance, so they may resort to begging and bargaining for recovery, especially when they know stories of people who were cured this way (CASTELLANOS et al., 2011; PÉRES; FRANCO; SANTOS, 2008).

My God, why won't you heal me, Lord? Have mercy on me, heal me from this diabetes. I've begged and still haven't seen my cure the way I want it to be (Claudionor). 
All interviewees reported using alternative remedies such as teas. They are practical solutions, such as the prescribed medication, and popular for coming closer to the sociocultural reality of the subjects (BARSAGLINI, 2006).

You can find videos on YouTube teaching how to make magnesium chloride. I was supposed to drink it 3 times a day, I drank it like water (Mauro).

They really teach it online, but we've used these products for 6 years now and what does it do? Nothing. The doctor gives him recommendations but he just won't follow them (Madalena).

The current role played by the internet and social media is noteworthy, expanding access to information, but may cause conflicts between biomedical and popular knowledge. In this context, the impact of fake news on health needs to be understood in order to be tackled (SOMMARIVA et al., 2018).

In the interviewees' narratives, the lack of access to information was unanimous (PUN; COATES; BENZIE, 2009). They regret that they are only now getting access to content that motivates lifestyle changes. The current moment, in contrast, is one of information overload, which leads to confusion.

I didn't even know what diabetes was, and it's been 40 years already (Milton)

If I had had the experience I have today, I wouldn't be where I'm at now (Doroteia).

At that time, we didn't have all the information we have available today (Zé).

I don't know what's better or not for the diabetic patient, they teach you too many things (Mauro).

The lack of control was observed as inherent to the diabetic patient be it due to sin, craving or addiction. This brings guilt and a feeling of impotence towards the disease (SOPHIA, 2015).

It was all my sin. Our sin is so big, we go through a lot of ordeal in this life (Claudionor).

You can't really control your cravings, you always want to eat something. It's the diabetes (Milton).

I can't cut out on bread. I just can't (Ivete).

The cultural value of food is an impactful aspect in the experience with DM2 (SATO et al., 2016). The high calorie diet reflects the belief the lower classes have in the need to keep themselves strong for work, which is often physical and tiring (Barsaglini, 2006). Interviewees also showed affection to certain foods, which is culturally constructed (SATO et al., 2016). Most emphasized their appreciation for 
flour, which makes up the cultural identity of Northeastern Brazil and an important source of carbohydrates. It is professionally recommended for the diabetic patient to suspend it (SBD, 2017).

Having sources of pleasure, identity and affective memories forbidden pains the diabetic patient, making it difficult to follow a diet seen as monotonous and without variety, required by an asymptomatic disease that appears late in life, after developing eating habits that are ingrained (BARSAGLINI, 2006; COSTA et al., 2011; PÉRES et al., 2007; SATO et al., 2016; SOPHIA, 2015; XAVIER,;BITTAR; ATAIDE, 2009). For those born in the countryside, there is also the idea that the food from their homeland is healthy, even though it is hypercaloric.

I didn't want to avoid eating it. I wouldn't eat it on a given day, but later I would eat it [...]. That food we planted and harvested right there, without pesticides, we shouldn't even be sick (Doroteia).

The diabetic patient is used to eating everything, how will I change it so suddenly? (Doroteia)

In the countryside it is common for us to eat our meals with flour. People just do it like that, it's a habit. The flour we have in the countryside isn't bad for you, it's natural, without chemicals [...]. Sometimes I have my daughter cook something different, because I'm sick of these foods (Claudionor).

Ivete, Zé, and one of Mauro and Madalena's children were diagnosed with DM2 relatively early, corresponding to the MODY type of the disease, which presents itself at a young age (SBD, 2017). Unlike DM1, which has greater short-term clinical repercussions when uncontrolled, such as diabetic ketoacidosis (SBD, 2017), the asymptomatic character of DM2 makes it complex for young patients to implement lifestyle changes. In these, the disregard for the disease is evident. In youth, when there are concerns about self-esteem, new discoveries and the need to be accepted by the group, the limitation imposed by diabetes is often ignored (CAVINI et al., 2016; PÉRES et al., 2007).

We have a kid who doesn't accept it. He's taken the insulin and still hasn't had breakfast, he eats more sugar than the older one who doesn't have diabetes, he eats in secret. Every day I talk to him about it (Madalena).

It wasn't easy for me to adapt to this diet plan at such a young age (Zé).

Vargas, Bernadete's husband, does not have DM2 but also shows difficulty in changing his lifestyle. Already in his eighties and living with the constant food 
sacrifices and hypoglycemia of the diabetic wife, his report raises a reflection on the need for autonomy of the elderly, in contrast to the "monotony" of the diabetic patient's routine (Péres et al., 2007).

I'm going to be 82 years old. What am I going to limit myself to? If I had diabetes and there was cake, I would eat it straight away.

It can be seen how the interviewees' conceptions that directly influence lifestyle changes may vary. The way in which, influenced by class, generation or access to information (SATO, 2016), diabetic patients interact culturally with society gives them their particular view of the disease and its control.

\section{Use and access to health care}

A consolidated Primary Health Care (PHC) is, to the Pan American Health Organization, the best model in a health system that seeks, among other outcomes, the prevention of complications of chronic diseases (Mendes, 2012). PHC in Brazil is guided by the Family Health Strategy (FHS), which has characteristics that enhance its preventive approach (MENDES, 2012), and is therefore an excellent strategy for encouraging DM2 patients to implement lifestyle changes. Salvador, however, has low FHS coverage (City Hall of Salvador, 2014).

The doctors at the unit just work there for six months. I've met eight or ten of them. I start getting close to one, and then he's gone (Reginaldo).

FHS is based on guidelines expressed in the PNAB, the National Primary Care policy (BRASIL, 2017). One of them is the longitudinality of care, which is the construction of a bond over time between the professional and the population, promoting trust and reference. The trust generated by the bond is a primary attribute so that professional actions for the patient's lifestyle changes can be more effective (BRASIL, 2017; DIAS; ALVES, 2019; EGGER; BINNS; ROSSNER, 2009; mendes, 2012). Reginaldo reports having obstacles to the success of the longitudinality of care, due to the turnover of professionals at the Family Health Unit close to his home.

The Research Center is a secondary care unit, with an endocrinology outpatient clinic. It is the only follow-up that some interviewees have for DM2, because they do not have a PHC unit nearby, or do not recognize the potential of care for their 
conditions in it. They mention the long wait between appointments. This reality reflects the huge demand for this service, which would be mitigated by better PHC coverage (BRASIL, 2017; Mendes, 2012). Having to wait too long between appointments may affect the bond and, therefore, the engagement for lifestyle changes (EGGER; BINNS; ROSSNER, 2009; Mendes, 2012).

Thank God I have all my doctors at the RC. The problem is the wait. I have to wait six months before I can get an appointment. It's always like that (Reginaldo).

We should have at least another RC in Bahia, in a strategic area, so that the people who live in the countryside don't have to come all the way here (Zé).

The territorialization of FHS is a guideline (BRASIL, 2017) with the potential to reduce the waiting time between appointments, by delimiting the population assigned to a given FHU (Family Health Unit). However, it needs to be carried out contemplating everyone in the nearby areas. Doroteia lives steps away from a unit, but she is not registered because her street is not listed in the area. She has trouble walking and was recently blinded by diabetes; therefore, she ends up depending on the solidarity of the workers in the unit.

You can only go if you live up until the gas station. If you live past it you need to go to another neighborhood, but I need someone to come with me, it's a long way. I'm lucky the staff helps me and attends me anyway.

Ivete and Milton predominantly use the private service. This is based on the logic of the market, which provides health care and products in a relationship of purchase and sale (MOL, 2008). The market logic is contrasted, according to Mol (2008), with the logic centered on care. The shared commitment between professional and patient is negotiated without the need to persuade patients through marketing and the offer of fast solutions. Not governed by market trends, the logic of care has greater freedom to offer valuable interventions for lifestyle changes, with a smaller offer because they do not seem profitable (MOL, 2008).

Ivete, used to market logic, wants and is encouraged to have a final product, such as a diet to follow, as a possible solution to her lack of food control. On the other hand, she does not understand the meaning of the educational work of the FHU nutritionist, even though she recognizes its effectiveness, which makes her a rare attendee.

I tried to get an appointment with the nutritionist at the unit. I went to her talks, but she only goes there to answer our questions. In the talks, I asked her questions and she answered them. She gave me recommendations on what to eat, and I follow them. But I wanted her to help me create a diet plan, my endocrinologist always says that to me. 
When patients depend on the Unified Health System in a city with low FHS coverage and other overloaded services, it can become common to delay the situation until it is an emergency (MENDES, 2012). Professionals in the emergency service do not have the time and care structure to work on lifestyle changes with their patients (PUN; COATES; BENZIE, 2009).

My mom has been told many times to look for an appropriate doctor, because it's an emergency service there, and her diabetes needs to be controled (Benedita).

Good integration in the levels of health care is how the local health system should promote better access and use of services (BRASIL, 2017; MENDES, 2012). However, it is clear that, in Salvador's reality, the incipient use or nonexistence of PHC results in transferring cases that could be treated, such as with the preventive approach generated by lifestyle change programs, to secondary care (RC), emergencies or supplementary assistance. These may not be able to work with a preventive model and become overloaded with demand, hindering access to it. Therefore, it is necessary to better plan the distribution and relationship in public care, and to understand, through supplementary assistance, that options closer to the logic centered on care must also be offered for lifestyle change.

\section{Professional-patient relationship}

The difficulty I had before was the fact that I didn't have any guidance. I went to the doctor but he only asked if I had diabetes, as they usually do (Jurandir).

Jurandir presented a history of clinical inertia in his life, frequent in the care of DM2 patients (COSTA; AZEVEDO, 2012; KHUNTI et al., 2013). This means clinicians or other professionals have the competence to assess whether previous behaviors for DM2 have been effective, but do not do so. In this sense, they also do not guide or reinforce the need for lifestyle changes (PUN; COATES; BENZIE, 2009). One factor that makes this reality possible is the lack of coordination and longitudinality of care, which would be better provided by PHC, to which the patient has not had access throughout their life. In PHC, a reference professional would be available for them (BRASIL, 2017).

Patients from the CR and one from the Family Health Units highlighted the importance of "diabetes groups" to change their experience with the disease. These are interdisciplinary groups (Antônio, 2010), connecting diabetic patients 
with professional mediators for health education in a playful way. The group is considered very successful by the participants due to the professionals' attention and interest in passing on information in a way that they can understand, in contrast to previous professional-patient relationship experiences, when they did not have such professional feedback.

Doctors need to be clear when explaining things to us. After all that happened to me, I found the RC group, that's where things made more sense to me. They are patient when explaining things and really care about us (Doroteia).

We were doing everything wrong! The way to inject insulin, the right position, how to store it, eating habits, everything. The RC group is like therapy, I finally found myself there and started dedicating myself to it all. I think of the day when they'll tell me "you don't need to come anymore". Of course, I will have to let someone else come and take my place, but I'll miss it a lot (Zé).

He tried to explain something, but I couldn't understand any of it (Claudionor).

The attention given to the sick person translates an empathic attitude, having therapeutic and motivational benefits and maintaining the bond, as opposed to a prohibitive, prescriptive posture, when the patient is passive and obedient to the established authority (BARSAGLINI, 2006; COSTA; AZEVEDO, 2012; DANTAS, 2009 ; EGGER; BINNS; ROSSNER, 2009; PUN; COATES; BENZIE 2009).

Other doctors said I couldn't do this or that. Really? And why is that? They wouldn't even look at my face, just prescribed something and barely looked at me. It bothered them if I asked twice. I think caring for the patient should be a priority (Doroteia).

However, the interviewees feel sad with the limited duration of the group as there are only a few weekly sessions. The RC demand does not allow for the reduction of bureaucracy in the access to the group, which ends up being reserved for those referred by a doctor due to their difficulty in controlling glycemic levels (Mendes, 2012). This was the advantage of the group promoted by one of the Family Health Units, which was equally highly rated. This happened continuously and for everyone in the area, although only one unit with NASF (Family Health Support Center) promoted it, which makes us reflect on the limitations of the minimum team and the importance of support from the multidisciplinary team (BRASIL, 2017).

The patient's motivation for lifestyle change is fundamental for it to be successful and to be maintained over time. Several studies show that professionals can contribute to motivation through systematic techniques that respect and act according to the stage where the patient is and if they are willing to change (DIAS; 
ALVES, 2019; EGGER; BINNS; ROSSNER, 2009 ). Such techniques explore a different clinical approach from the traditional one, emphasizing the patient as an active subject and co-responsible for their success, encouraging self-care, autonomy of choice, identifying difficulties, deciding on alternatives and setting new goals together (DIAS; ALVES, 2019; EGGER; BINNS; ROSSNER, 2009; MOL, 2008). Even without systematization, when simple acts recommended by these techniques were used by the interviewees' professionals, such as praising minimal progress or motivating gradual changes (DIAS; ALVES, 2019), they proved to be effective.

She encouraged me: "congratulations, you're doing great!" That is really encouraging. It's different from "you can't do that" (Zé).

We saw the nutritionist at the unit. She said: "if you eat a glass of flour, try to eat a little less”. I still eat it, but I've cut down on flour a lot (Mauro).

Motivational techniques are connected with the Person-Centered Clinical Method, which synthesizes this integral, customized and cooperative vision of care. FHS officially values the use of the method, stressing that it contributes to its success as a strategy (BRASIL, 2017).

An authoritarian or distanced posture, in which there is blame, fear, prescription of strict and inflexible controls and the outsourcing of explanations on paper was poorly evaluated by respondents, who did not feel motivated this way and even felt distressed (DIAS; ALVES, 2019; EGGER; BINNS; ROSSNER, 2009).

No one has time to read, no one has the physical condition, like me, with my vision. We put it away, we do something when we remember it, because no one is going to take all that bunch of paper to read it every day (Doroteia).

Wow, doctor, look at this! I was losing so much weight, I weighed 50 kilos. I was shaking, falling in the middle of the street because of these diets. When I was working, I couldn't even pick up a bag of cement anymore. The doctor just said that I wasn't eating well, but I was following the plan properly (Reginaldo).

The doctor is getting a little nervous. She thinks I don't eat right, but I take notes of what I eat, what I don't eat, I do it right. This makes us nervous. I get nervous (Bernadete).

The great demand for services and, consequently, little consultation time clarify but do not explain these phenomena, which seem to have their origin in the deficient ethical-humanistic university education and in the super-specialization and fragmentation of care among many professionals, culminating in a reductionist view of the patient (COSTA; AZEVEDO, 2012; EGGER; BINNS; ROSSNER, 
2009; KHUNTI et al., 2013). This can lead to a prescriptive posture, relying on professional authority as sufficient, a posture that frustrates the professional due to its inefficiency when it comes to lifestyle change (EGGER; BINNS; ROSSNER, 2009; PUN; COATES; BENZIE 2009). The Person-Centered Clinical Method and motivational techniques need to be known and adapted by professionals at all levels of care, for their benefits in the care of chronic diseases (MENDES, 2012).

\section{Social support}

The exchange of experiences was also mentioned in the "diabetes groups" of the RC. My friends there, they have the same problem as me, they talk to me, they say, 'so, do you think you're getting better?' We have this kind of conversation there [...] I always remember everything we talked about (Jurandir).

Social support is crucial for lifestyle change. Allowing the exchange of experiences among diabetic patients is motivating, encourages self-care, encourages acceptance of the patient's condition and the need for change, and brings the feeling of belonging. In addition to the support of people facing the same pathology, support from family and other social groups is also significant (ANTÔNIO, 2010; CUNHA; CHIBANTE; ANDRÉ, 2014; PUN; COATES; BENZIE, 2009; XAVIER; BITTAR; ATAÍDE, 2009).

In the family, however, conflicts may happen when there is overload on members that are informal caregivers (TRINDADE et al., 2017). Therefore, for Benedita, her mother's only caregiver, conflicts become unavoidable, harming the well-being of both and due to overload the caregiver sometimes ends up leting the patient eat what they like.

Sometimes I give her some fried passarinhas $^{1}$, I shouldn't but I do it just so she doesn't get too annoying.

The interviewees' wives became their husbands' informal caregivers. A gender issue can be noticed: they prepare their meals, make appointments, accompany them and encourage control. Some of the husbands are afraid of doctors, delay appointments, depend on their wives' care, and often do not internalize the need to mobilize for lifestyle changes on their own. They even tend to eat in secret, when alone. Women get highly exhausted due to the many roles, of worker, wife, unsuccessful caregiver and mother, harming the marital relationship (mon, 2017; Trindade et al., 2017). 
I always tell him, when I start to work, things get out of hand. I always have to be doing something. Sometimes I get home so tired, I work every day, and I always have to get up in the middle of the night to give him something to eat [...] he doesn't like seeing doctors. I tell him he has to go. I have to do everything, book appointments, take him there [...] I buy fruit, everyone eats it, but if I don't buy it again, no one else does (Madalena).

Social events often use food in get-togethers and, therefore, are a source of anguish for the interviewees (BARSAGLINI, 2006; PÉRES et al., 2007; PUN; COATES; BENZIE, 2009). The need for social recognition of the specificities of patients with diabetes is perceived, which brings the importance of educational campaigns aimed not at the diabetic patient, but at their families and caregivers.

My sister is going to a party on Sunday. I'll stay, because it's not wise of me to go. This could make me become antisocial, but oh well, those are the consequences (Zé).

Conceição, with a complicated family network due to the fact that her son is a drug user, sees her emotional situation as a priority, to the point of believing that this is where diabetes comes from. She smokes a lot and overeats due to emotional exhaustion. In this context, the support of the community agent is the only support she gets, which shows the potential of comprehensive care when the PHC is active (BRASIL, 2017).

Getting very angry causes diabetes, I think. I have a son, if God helped me, if something happened to get him out of my house, it would be a blessing [...] The community agent always comes here, she's like a friend to me.

Ivete, also with little social support, sees this as an impediment to following guidelines for physical activity.

I arrive in time to do it, but I have no incentive. There's a nice square in my neighborhood, lots of people walk there, I live close to it, but I have no one to come with me, it's really hard to do this on my own.

It is noted that the absence of social support hinders the motivation for lifestyle change (PUN; COATES; BENZIE 2009). When there is social support, especially family support, it can be conflictual, affect the well-being of those involved and end up leading to concessions. It is important, therefore, that professionals also pay attention to family members and people responsible for the care in order to help settle conflicts, provide clarifications and offer support in the case of caregiver overload (MON, 2017; TRINDADE et al., 2017). 


\section{Environment}

The occupation that the respondent had or has influences lifestyle change (BARSAGLINI 2006; PÉRES; FRANCO; SANTOS, 2008).

Truck drivers only eat fatty food and never at a specific time. If you go to an all-you-can-eat restaurant, you eat a lot, a lot of people eat a lot. Many times you only eat once a day, lunch, and set off (Milton).

Physical activity and a balanced diet, that's just for people who have time for that (Milton).

I had to take food from home, because the foods we had at work, they always said "this diet thing, there's no way to do that here" (Reginaldo).

It started when I was working there, I was always in a hurry, I ate when I had time to eat, I never ate a regular meal like a diabetic patient is told to do. I never left early, so I had dinner there too. When I left work I was really tired. It's super tiring (Ivete).

The cost of wholegrain and diet products and a varied diet were also mentioned (BARSAGLINI, 2006; PÉRES et al., 2007; PUN; COATES; BENZIE 2009).

Paying for rent, clothes, medication, there's not much money left. It's impossible to have good eating habits (Madalena).

Moderate aerobic exercise such as walking is excellent for controlling diabetes (SBD, 2017) and can take place in public spaces. For this, there must be safety (BUSS; FILHO, 2007). Reginaldo lives in a neighborhood with frequent shootings and the presence of drug dealers. Physical activity in neighborhoods with a similar profile is certainly demotivating.

Sometimes about six boys go by, all carrying guns. I'm not gonna get out of my house.

Ivete compares the area where she lives now with where she used to live, which is where she currently works.

It's much worse here. The area where I live is a nice place, there's green, there's the square where people go for walks. I find it safer than here. This street is always empty, I can't go for a walk on my own at the nearest square. Where I live now, I go out sometimes (Ivete).

The city's public transport system, its diversified use of space, green areas and urban design decisively influence the number of people on the street and, consequently, the sense of safety, leading to active commuting, whose definition is incidental movement on foot or bicycle for occupational, leisure and consumption activities (JACOBS, 2014; WHO, 2008). Active displacement can stimulate lifestyle change spontaneously, without great sacrifice. Accessibility is not part of urban 
design and the city of Salvador has infrastructure problems for diabetic patients with complications. Claudionor, using a wheelchair due to the amputations she suffered, talks about the Historic Center, where she lives.

These cobblestone streets are not good for me, I use a wheelchair. I've been knocked down twice.

Her daughter makes an effort pushing her on the steep slopes of the area and still needs to lift her to go up the narrow sidewalks, without a ramp for wheelchair users, having to ask street vendors to clear the way so they can pass. This is the route taken to get to the neighborhood's Family Health Unit. Therefore, Claudionor often fails to go to appointments. To leave the region and go to RC, "two buses that take a long time" are needed. Reginaldo, whose diabetes compromises his vision, and Mauro also report difficulties with public transport.

I can't see well, I see the sides of the bus, there are the numbers there, this one is 1224, I know it already. I mean, at night, because during the day it's so hard (Reginaldo).

The transport is a mess. Now there's only one bus line. It's hard to get to the doctor's office, and I'm always late. It's good to live in the center though, because many places are at a walking distance (Mauro).

The distances in the center of Salvador, of colonial origin, before motorized vehicles (RISÉRIO, 2004) are smaller, making it possible to walk between neighborhoods. This and the diversified use of the space with commerce and other services, allows for an intense occupation of the area by pedestrians. Mauro, however, who uses crutches due to amputation, reports difficulties precisely because of the intense movement of people on the area's narrow sidewalks, which do not meet the demand (JACOBS, 2014).

Sometimes I go out and run errands, but there are so many people outside that I'm afraid someone will step on me.

Milton, who lives between the Historic Center of Salvador and the Minas Gerais state countryside, compares the two realities. Here he discusses the topography of the area, the conflict between pedestrians and drivers, and the importance of green areas (WHO, 2008).

Walking around here is almost impossible, because of the slopes [...] I'd never ride a bike here in Salvador. To me the traffic here is the most dangerous in Brazil. Drivers don't care about pedestrians. In a lot of cities in Minas Gerais, car drivers stop for you to cross the street. 
I exercise more in Minas. There is a stream there, and they built a sidewalk at the edge of the stream, it became a walking path. It is even healthier to walk along the edge of the stream, there I walk 5 times a week. Here I'm lazy.

Therefore, aspects that do not depend on the control of professionals and patients are also determinant for the difficulty in changing lifestyle (BUSS; FILHO, 2007). These depend on the initiative of employers, the government and industries, in order to produce better quality food at affordable prices, and provide conditions so that diet and physical activity can be implemented.

\section{Conclusion}

In the final analysis, lifestyle changes will always be a decision of the diabetic patient. All the factors analyzed here facilitate or hinder decision making to change habits. By understanding this multifactoriality, the health professional can plan more effective strategies, in collaboration with the patient. Public policies also need this analysis to be discussed and implemented.

This study can generate hypotheses and direct quantitative investigations; however, due to its qualitative characteristic, it does not allow generalizations to be obtained (MINAYO, 2014). Therefore, further studies will increase knowledge on the subject, thus improving the basis for interventions.

\section{References}

ANTÔNIO, Patrícia. A psicologia e a doença crônica: intervençáo em grupo na diabetes mellitus. Psicologia, Saúde e Doenças, Lisboa, v. 11, n. 1, p. 15-27, 2010.

BARSAGLINI, Reni Aparecida. Pensar, vivenciar e lidar com o diabetes. 2006. Tese (Doutor em Saúde Coletiva) - Faculdade de Ciências Médicas, Universidade Estadual de Campinas, Campinas, SP, 2006. Available at: <http://repositorio.unicamp.br/bitstream/ REPOSIP/313829/1/Barsaglini_ReniAparecida_D.pdf>. Accessed on: October 9, 2019.

BRASIL. Ministério da Saúde. Portaria n. 2436, de 21 de setembro de 2017. Aprova a Política Nacional de Atenção Básica, estabelecendo a revisão de diretrizes para a organização da Atenção Básica, no âmbito do Sistema Único de Saúde (SUS). Diário Oficial da União, Brasília, DF, 21 de set. 2017. Available at: <http://bvsms.saude.gov.br/bvs/saudelegis/gm/2017/ prt2436_22_09_2017.html>. Accessed on: October 9, 2019. 
BRASIL. Ministério da saúde. Vigitel Brasil 2018: vigilância de fatores de risco e proteçâo para doenças crônicas por inquérito telefônico. Brasília, DF, 2019. Available at: <https://portalarquivos2. saude.gov.br/images/pdf/2019/julho/25/vigitel-brasil-2018.pdf>. Accessed on: 5 out. 2019.

BUSS, Paulo Marchiori; PELLEGRINI FILHO, Alberto. A Saúde e seus Determinantes Sociais. PHYSIS: Rev. Saúde Coletiva, Rio de Janeiro, v. 17, n. 1, p. 77-93, jan./apr. 2007.

CASTELLANOS, Marcelo Eduardo Pfeiffer et al. Evidências produzidas por pesquisas qualitativas sobre diabetes tipo 2: revisão da literatura. Interface - Comunic., Saude, Educ., Botucatu, SP, p. 1-17, 2010.

CAVINI, Flávia Lemes et al. Vivências de adolescentes com diabetes: uma abordagem fenomenológica. Rev enferm UFPE, Recife, PE, p. 805-13, 2016.

CLARK, Helen. NCDs: a challenge to sustainable human development. The Lancet, v. 381, issue 9866, p. 510-511, feb. 2013.

COSTA, Fabrício Donizete da; AZEVEDO, Renata Cruz Soares de. Empatia, relação médicopaciente e formação em medicina: um olhar qualitativo. Rev. bras. educ. med., Brasília, DF, v. 34, n. 2, p. 261-269, 2012.

COSTA, Jorge de Assis et al. Promoção da saúde e diabetes: discutindo a adesão e a motivação de indivíduos diabéticos participantes de programas de saúde. Ciênc. Saúde Coletiva, Rio de Janeiro, v. 16, n. 3, p. 2001-2009, 2011.

DANTAS, Jurema Barros. Tecnificação da vida: uma discussão sobre o discurso da medicalizaçáo da sociedade. Fractal, Revista de Psicologia, Rio de Janeiro, v. 21, n. 3, p. 563-580, sept./dec. 2009.

DIAS, Ruth Borges; ALVES, Luciana. Estratégias comportamentais e de motivação para mudanças de hábitos de vida voltados para a saúde. In: GUSSO, Gustavo; LOPES, José Mauro Ceratti; DIAS, Lêda Chaves (org.). Tratado de medicina da familia e comunidade: princípios, formação e prática. 2. ed. Porto Alegre: Artmed, 2019. p. 1885-1905.

DOMÍNGUEZ MON, Ana. Los cuidados de la salud en personas que viven con diabetes: enfoque etnográfico antropológico y perspectiva de género. Salud Colectiva, v. 13, n. 3, p. 375 $390,2017$.

EGGER, Gary J; BINNS, Andrew F; ROSSNER, Stephan R. The emergence of "lifestyle medicine" as a structured approach for management of chronic disease. $M J A$, v. 190, n. 3, p. 143-145, 2009.

INTERNATIONAL DIABETES FEDERATION - IDF. Diabetes atlas. 8. ed. 2017. Available at: <http://fmdiabetes.org/wp-content/uploads/2018/03/IDF-2017.pdf>. Accessed on: October 9, 2019.

JACOBS, Jane. Morte e vida de grandes cidades. São Paulo: Martins Fontes, 2014. 
KHUNTI, Kamlesh et al. Clinical inertia in people with type 2 diabetes: a retrospective cohort study of more than 80,000 people. Diabetes Care, v. 36, n. 11, p. 3411-3417, nov./oct. 2013.

LIRA, Geison Vasconcelos; CATRIB, Ana Maria Fontenelle; NATIONS, Marilyn K. A narrativa na pesquisa social em saúde: perspectiva e método. RBSP, v. 16, n. 1/2, p. 59-66, 2003.

MENDES, Eugênio Vilaça. O cuidado das condiçôes crônicas na atenção primária à saúde: o imperativo da consolidação da estratégia saúde da família. Brasília, DF: Organização PanAmericana da Saúde, 2012. ebook. Available at: <http://bvsms.saude.gov.br/bvs/publicacoes/ cuidado_condicoes_atencao_primaria_saude.pdf>. Accessed on: October 9, 2019.

MINAYO, Maria Cecilia de Souza. O desafio do conhecimento. 14. ed. São Paulo: Hucitec, 2014. MOL, Annemarie. The logic of care: health and the problem of patient choice. New York: Routledge, 2008.

MOL, Annemarie; LAW, John. Acción encarnada, cuerpos actuados, el ejemplo de la hipoglucemia. In: MARTIN, Rebeca Ibáńez; SEDENO, Eulalia Pérez (org.). Cuerpos y Diferencias. Madrid: Plaza y Valdez, 2012. p. 153-177.

PUN, Sandra PY; COATES, Vivien; BENZIE, Iris FF. Barriers to the self-care of type 2 diabetes from both patients' and providers' perspectives: literature review. Journal of Nursing and Healthcare of Chronic Illness, v. 1, p. 4-19, feb. 2009.

PÉRES, Denise Siqueira et al. Dificuldades dos pacientes diabéticos para o controle da doença: sentimentos e comportamentos. Rev. Latino-am Enfermagem, Ribeirão Preto, SP, v. 15, n. 6, nov./dez. 2007.

PÉRES, Denise Siqueira; FRANCO, Laércio Joel; SANTOS, Manoel Antônio dos. Sentimentos de mulheres após o diagnóstico de diabetes tipo 2. Rev. Latino-am. Enfermagem, Ribeirão Preto, SP, v. 16, n. 1, jan./feb.

PREFEITURA MUNICIPAL DE SALVADOR. Secretaria Municipal da Saúde. Plano municipal de saúde 2014-2017. Salvador, 2014. Available at: <http://www.saude.salvador.ba.gov. br/arquivos/astec/pms_2014_2017_versao_preliminar.pdf>. Accessed on: October 9, 2019.

PREFEITURA MUNICIPAL DE SALVADOR. Secretária de Desenvolvimento e Urbanismo - SEDUR. Regióes administrativas do município. Salvador, 2008. Mapa.

RISÉRIO, Antônio. Uma história da cidade da Bahia. 2. ed. Rio de Janeiro: Versal, 2004.

SATO, Priscila de Morais et al. The use of Pierre Bourdieu's distinction concepts in scientific articles studying food and eating: A narrative review. Appetite, p. 174 -186, 2016.

SILVA, DeniseMaria Guerreiro Vieira. Narrativasdovivercom diabetesmellitus: experiênciaspessoais e culturais. 2000. Tese (Doutor em Enfermagem) - Centro de Ciências da Saúde, Universidade 
Federal de Santa Catarina, Florianópolis, SC, 2000. Available at: <https://repositorio.ufsc.br/ xmlui/bitstream/handle/123456789/78129/153093.pdf?sequence=1\&isAllowed $=y>$. Accessed on: October 9, 2019.

SOCIEDADE BRASILEIRA DE DIABETES - SBD. Diretrizes da Sociedade Brasileira de Diabetes (2017-2018). São Paulo: Clannad, 2017. Available at: <https://www.diabetes. org.br/profissionais/images/2017/diretrizes/diretrizes-sbd-2017-2018.pdf>. Accessed on: October 9, 2019.

SOMMARIVA, Silvia et al. Spreading the (fake) news: exploring health messages on social media and the implications for health professionals using a case study. American Journal of Health Education, 2018.

SOPHIA, Bianca. A compulsão alimentar como objeto de pesquisa da antropologia das emoçôes. INTRATEXTOS, Rio de Janeiro, v. 6, n. esp. 1, p. 85-108, 2015.

TRINDADE, Irene et al. Caracterização do grau de sobrecarga dos cuidadores de utentes dependentes da unidade de saúde familiar USF descobertas. Rev. Port. Med. Geral Fam., Lisboa, v. 33, p. 178-86, 2017.

WORLD HEALTH ORGANIZATION - WHO. A glossary of terms for community health care and services for older persons. 2004. Available at: <https://apps.who.int/iris/bitstream/ handle/10665/68896/WHO_WKC_Tech.Ser._04.2.pdf?sequence=1\&isAllowed=y>. Accessed on: October 9, 2019.

WORLD HEALTH ORGANIZATION - WHO. A healthy city is an active city: a physical activity planning guide. Copenhagen, 2008.

XAVIER, Antônia Tayana da França; BITTAR, Daniela Borges; ATAÍDE, Márcia Barroso Camilo de. Crenças no autocuidado em diabetes - implicaçóes para a prática. Texto Contexto Enferm., Florianópolis, SC, v. 18, n. 1, p. 124-30, jan./mar. 2009

\section{Nota}

${ }^{1}$ Typical food from Salvador, consisting of ox fried spleen. 


\section{Resumo}

Experiências e narrativas de portadores de diabetes mellitus tipo 2 na cidade de Salvador (Bahia) sobre dificuldades para a mudança dos estilos de vida

A dificuldade para os portadores de diabetes mellitus tipo 2 mudarem os estilos de vida conforme as orientaçóes profissionais possui magnitude considerável. Tal fato contribui para manter o controle da doença aquém do desejável, e pode levar ao aumento da morbimortalidade e custos para o sistema de saúde, com complicaçóes que poderiam ter sido evitadas. Este estudo qualitativo, diante da importância de se compreender este fenômeno para melhor intervenção, explora narrativas e experiências de 10 portadores de diabetes na cidade de Salvador, comparando-as com a literatura a fim de analisar como determinantes sociais lhe são influenciadores. Conclui-se que é um fenômeno multifatorial, e aspectos como concepçóes sobre a doença e seu controle, uso e acesso aos serviços de saúde, relacionamento profissional-paciente, suporte social, e ambiente, personalizam cada vivência com a doença, facilitando ou não a motivação para a mudança. Profissionais de saúde e poder público devem se sensibilizar para tais aspectos, e encontram no texto sugestōes para contribuir na mitigação de dificuldades e facilitar um estilo de vida preventivo aos adoecidos.

> Palavras-chave: Diabetes mellitus tipo II; Estilos de vida; Estudo qualitativo; Prevenção e controle; Determinantes sociais da saúde. 